\title{
ROLE OF HONEY BEE ON MUSTARD (Brassica SPp.) YIELD
}

\author{
Hossain, M. S., J. K. Paul, M. M. Rahman, M. U. Fazlullah, and S. Sarkar ${ }^{1}$ \\ Department of Entomology, Sher-e-Bangla Agricultural University, Dhaka, Bangladesh; ${ }^{1}$ Department of \\ Agricultural Botany, Sher-e-Bangla Agricultural University, Dhaka, Bangladesh
}

\begin{abstract}
The study was conducted in the field at Nagarpur, Tangail, Bangladesh, from November 2016 to February 2017 to find out the role of honey bees on mustard yield. Honey bee (Apis mellifera) was the main insect pollinator during mustard flowering season. Mustard seeds of variety Tori-7 were selected for this experiment. Three different treatments were used, viz. control, netting with honey bees and netting without honey bees. Honey bees helped mustard pollination, but decreased the flowering period ( 6 days) of the mustard plant. Honey bees assisted the pollination of mustard and increased the number of pod per plant (14\%) as well as the number of seeds per pod (11\%). Honey bees enhanced the pollination of mustard plant, and netting with honey bees increased the mean seed yield (15\%) per plant of mustard, however, decreased the period of flowering stage of mustard. Mustard yield was considerably higher in honey bee foraging plots.
\end{abstract}

Key words: Honey bee; Mustard; Pollination; Foraging; Yield components.

\section{INTRODUCTION}

Mustard (Brassica spp.) belonging to the family Cruciferae is an important oil seed crop, cultivated for edible oil throughout Bangladesh. It is one of the leading oil seed crops in the world. It plays a vital role in human nutrition. It is used as a condiment, salad, green manure and fodder crop, and leaf and stem as a vegetable in the various mustard growing countries of the World (FAO 2004). It is an open pollinated crop and honeybees are effective pollinators for the open pollinated crops because of a lot of nectar and pollens are available on the flower of mustard. In Bangladesh, more than 361.909 thousand metric tons of rape and mustard produced from a total of 787.025 thousand acres of land in the year 2015-2016 (BBS 2017). Domestic production of edible oil almost entirely comes from rape seed and mustard occupying only about $2.73 \%$ area of total cropped area in Bangladesh (BBS 2017). The annual oil seed production in the same year was 0.933 million tons of which the share of rapeseed-mustard was 0.362 million tons, which come about $69.94 \%$ of the total edible oil seed production (BBS 2017).

Mustard occupies the top of the list in respect of area and production compared to other oilseed crops grown in Bangladesh. Cross pollination of entomophile crops by honey bees are considered as one of the effective and the cheapest methods for triggering the crop yield both qualitatively and quantitatively (Singh et al. 2005 and Mohapatra et al. 2010). Honeybees are very important social insect known as the most economically valuable insect because of its honey production and pollinating activities (Lawal and Banjo 2010). The principal role of honey bee in agriculture is pollination. These insects are of great economic importance because they not only produce honey and bee wax, but also act as primary pollinating agents of many agricultural and horticultural crops.

Honey bees are among the most important pollinating insects found within orchards and modern agricultural systems (Williams 1994, Morse and Calderone 2000). There are many species of honeybee, but four species are common these are Apis florae, A. dorsata, A. cerana and A. mellifera. Due to domestic nature, Apis mellifera is the most popular worldwide and can be easily reared and safely migrated from one place to other for pollination and honey production (FAO 1986). Like other honeybee species, A. mellifera has a high flight range for foraging (maximum 2-3 km away from its colony) (Abrol 1997). Foragers take care of bringing from the environment everything that the colony needs to the hive: pollen, nectar, water and propolis (Ameco 2012). Of the 100 crops that provide $90 \%$ of the 
world's food, 71 are bee pollinated, and honey bees (A. mellifera) are the managed pollinator conscripted to provide the necessary pollination services for most of these crops (FAO 2005). Honey bees, like other insects, are reasonably sensitive to a range of chemical insecticides (Devillers et al. 2002, Stefanidou et al. 2003, Hardstone and Scott 2010), and bees close to agricultural areas are particularly vulnerable to pesticide exposure through multiple routes (Krupke et al. 2012). Over the past decade, there has been a sharp increase in the number of honey bee colony losses in the United States, often exceeding 30\% per year (Lee et al. 2015).

Pollinators and pollination are important for crop yield. Hence, the present study was undertaken to study the role of honey bees on mustard yield in Bangladesh perspective.

\section{MATERIAL AND METHODS}

The experiment was carried out during the period from November 2016 to February 2017 to find out the effect of honey bee foraging in mustard field and role of honey bee on mustard yield. The study was conducted in the field at Nagarpur, Tangail. The soil of the experimental area belongs to the Modhupur Tract under AEZ No. 28 and it was dark grey terrace soil.

The mustard seeds of variety Tori-7 were selected for this experiment. The variety was local one and improved by the Bangladesh Agricultural Research Institute (BARI) in the year of 2004. The plant height of this variety ranges $60-75 \mathrm{~cm}$ and the life cycle is $70-75$ days when cultivated in robi season. The experimental plot was opened in the first week of November 2016 with a power tiller, and was exposed to the sun for a week, after which the land was harrowed, ploughed and cross-ploughed several times followed by laddering to obtain a good tilt. Weeds and stubble were removed, and finally obtained a desirable tilt of soil for sowing mustard seeds.

The experiment was conducted considering three treatments and laid out in a completely randomized design (CRD). Each treatment was replicated four times. Field trials were conducted during the winter season in the field at Nagarpur, Tangail. The unit plot size was $2.5 \mathrm{~m} \mathrm{x} 1.2 \mathrm{~m}$. The distance between plots and blocks was $50 \mathrm{~cm}$ and $100 \mathrm{~cm}$, respectively. Row to row distance for mustard was $25 \mathrm{~cm}$. Similar distance was maintained when seeds were sown.

The fertilizers N, P, K, S, Zn and B in the form of Urea, TSP, MP, Gypsum, Zinc sulphate and borax, respectively were applied. The entire amount of TSP, MP, Gypsum, Zinc sulphate and borax were applied during the final preparation of land. Urea was applied in two equal installments at final land preparation and at 30 days of seed sowing.

The seeds of mustard were sown in sole and in intercrop plot on 26 November 2016. After establishment of seedlings, all other intercultural operations, such as thinning, weeding and irrigation were accomplished, when necessary, for better growth and development of the mustard crop. Single irrigation had been applied just once before flower initiation. The plots were provided with wellarranged drainage facilities including the facility of removing excess rain water, if any. Weeding was done twice in the field to keep the plots free from weeds ensuring better growth and development of the crops.

The newly emerged weeds were uprooted carefully at flowering stage by mechanical means. For the experiment a piece of net was set up over selected plot on 18 December 2016, so that only honey bees present in the selected plots. The net size was $2.5 \mathrm{~m} \times 1.2 \mathrm{~m} \times 2.5 \mathrm{~m}$. For the experiment, boxes were set up over selected plots on $31^{\text {st }}$ December 2016.

Mustard harvesting at maturity (days of sowing) was done manually in each plot. The harvested crops of each plot was bundled separately, properly tagged and brought to shade. Care was taken for harvesting, threshing and also cleaning of mustard. The seeds were cleaned and finally the weight was recorded and converted into per hectare yield. Mustard of each plot was threshed separately, cleaned, sun dried, weighed and packed. 
Data were analyzed by IBM SPSS 25 software for proper interpretation. The data recorded on different parameters were subjected to analysis of variance (STAT Graphics Centurion XV) and means were compared by Duncan's Multiple Range Test (STAT Graphics Centurion XV) at 5\% level of significance.

\section{Flowering period}

\section{RESULTS AND DISCUSSION}

The highest flowering period of mustard was recorded 56 days when mustard field was netted without bees $\left(\mathrm{T}_{1}\right)$ and 51 days in $\mathrm{T}_{3}$ (Control/Open treatment). On the other hand, the lowest period of flowering was recorded 45 days at the treatment of netting of mustard field with bees $\left(\mathrm{T}_{2}\right)$ (Fig. 1). From the figure 1 it was revealed that honey bees helped more in the pollination of mustard and reduced the period of flowering mustard than the pollination without honey bees and in the open field.

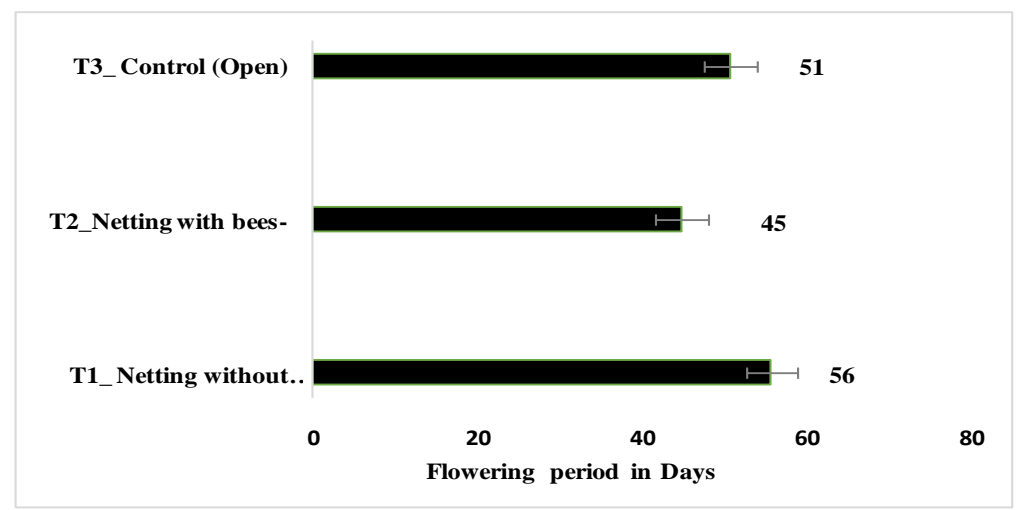

Fig. 1. Flowering period in days of mustard at different treatments.

\section{Number of Pod Production}

The highest number of pods produced per plant was recorded 131.38, when mustard field was netted with honey bee which was statistically different from other treatments. On the other hand, the lowest number of pods per plant was recorded 107.75 pods per plant when mustard field was netted without honey bees which was statistically similar with control or open field (115.5 pods per plant) (Fig. 2).

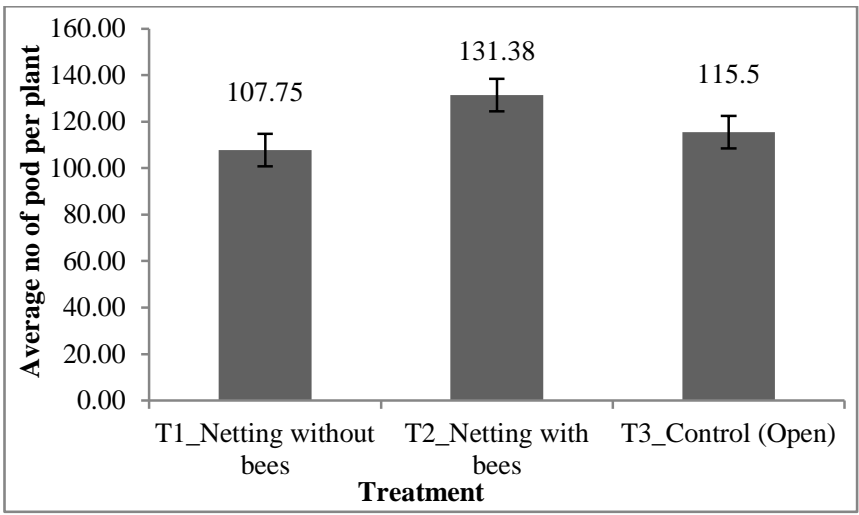

Fig. 2. Number of pods per plant at different treatments.

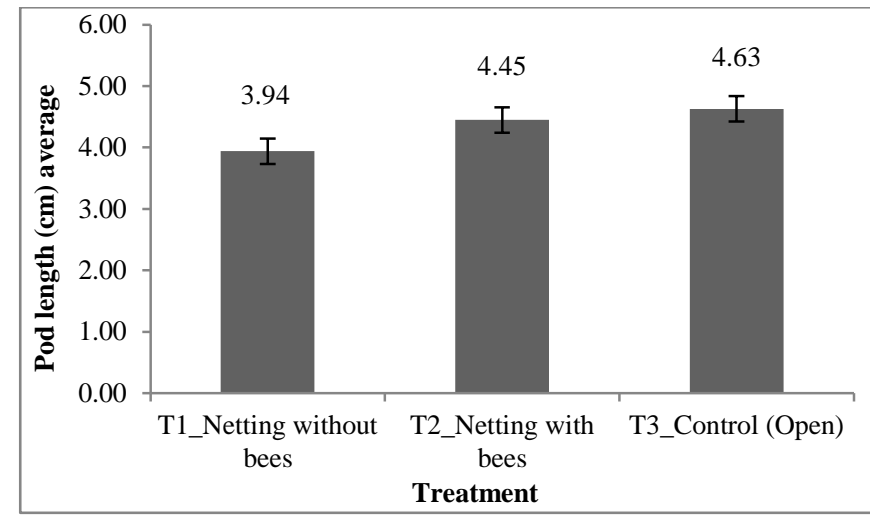

Fig. 3. Pod length in different treatments.

The flowering period of mustard at different treatments revealed that honey bees helped in the pollination of mustard and increased the number of pods per plant of mustard than the pollination without honey bees and open field (Fig. 2). 


\section{Pod Length}

The highest number of pod length was recorded $4.63 \mathrm{~cm}$ in mustard field $\left(\mathrm{T}_{3}\right)$ which was statistically similar to the field netting with honey bees $\left(\mathrm{T}_{2}\right)(4.45 \mathrm{~cm}$ pod length). On the other hand, the lowest pod length was recorded $3.94 \mathrm{~cm}$ in the mustard field netted without honey bees (Fig. 3). From the above Fig. 3 it is revealed that honey bees helped in the pollination of mustard. The pod length of mustard was higher in open field than the pod length in that of the mustard field without honey bees.

\section{Number of Seeds per Pod}

The highest number of seeds produced per pod was recorded 19.13 when the mustard field was netted with honey bees $\left(\mathrm{T}_{2}\right)$ which was statistically different from other treatments and followed by 17.25 seeds per pod in case of control or open mustard field $\left(\mathrm{T}_{3}\right)$. On the other hand, the lowest number of seeds per pod was recorded 12.38 when mustard field was netted without honey bees (Fig. 4). From the Fig. 4 it is revealed that honey bees helped in pollination of mustard and increased the number of seeds per pod of mustard in the netted field than in the field without honey bees and open field.

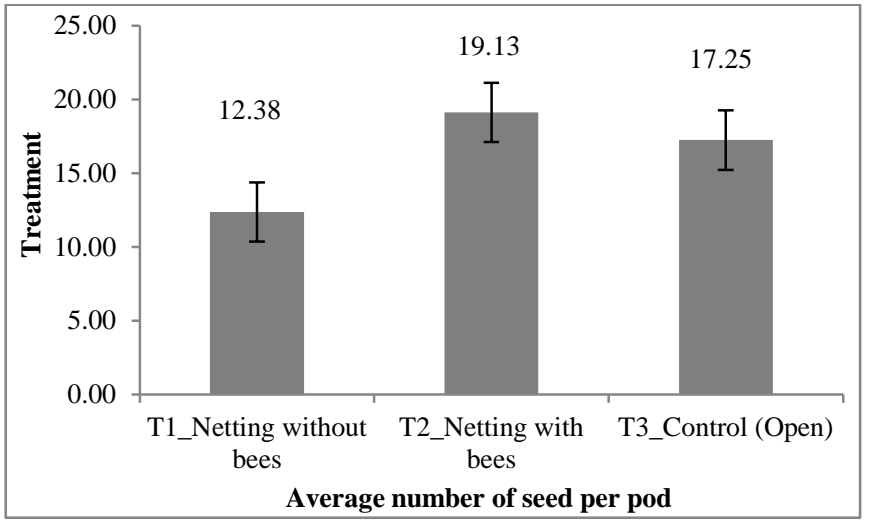

Fig. 4. Average number of seeds per pod in different treatments.

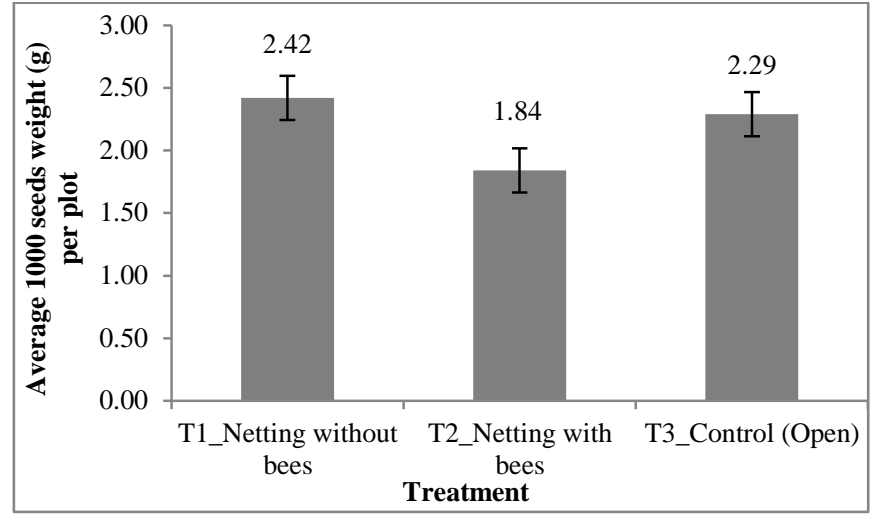

Fig. 5. The weight of 1000 seeds per plot in treatments.

\section{Seed Weight}

The highest weight of 1000 seeds per plot of mustard was recorded $2.42 \mathrm{~g}$ when the mustard field was netted without honey bees $\left(\mathrm{T}_{1}\right)$ which was statistically more or less similar $(2.29 \mathrm{~g})$ weight of the same number of pods per plot of mustard in the control or open field $\left(\mathrm{T}_{3}\right)$. On the other hand, the lowest weight of the 1000 seeds per plot of mustard was recorded $1.84 \mathrm{~g}$ when the mustard field was netted with honey bees (Fig. 5). It is revealed that the weight of mustard seeds produced per plot was more in netting without honey bees than the netting with honey bees and open field.

\section{Seed Yield per Plant}

The highest seed yield per plant of mustard was recorded $5.48 \mathrm{~g}$ when mustard field was netted with honey bees $\left(\mathrm{T}_{2}\right)$ which was significantly different from other treatments. On the other hand, the lowest seed yield per plant of mustard was recorded $3.56 \mathrm{~g}$ when the mustard field was not netted with honey bees $\left(\mathrm{T}_{1}\right)$ which was statistically insignificant with $4.78 \mathrm{~g}$ of seed yield per plant of mustard in case of control or open field $\left(\mathrm{T}_{3}\right)$ (Fig. 6). It is revealed that honey bees helped in the pollination of mustard. Netting with honey bees increased more seed yield per plant of mustard than the field netting without honey bees and open field.

\section{Yield per plot}

The highest yield per plot of mustard was recorded $585.25 \mathrm{~g}$ when mustard field was netted with honey bees $\left(\mathrm{T}_{2}\right)$ which was statistically significant from other treatments. On the other hand, the lowest 
yield per plot of mustard was recorded $395.75 \mathrm{~g}$ when mustard field was netted with honey bees $\left(\mathrm{T}_{1}\right)$ which was statistically insignificant with $456.63 \mathrm{~g}$ of yield per plot of mustard in case of control or open field $\left(\mathrm{T}_{3}\right)$ (Fig. 7).From the Fig. 7 it is revealed that honey bees aided pollination of mustard and increased the yield of mustard per plot more than the pollination without honey bees and open field.

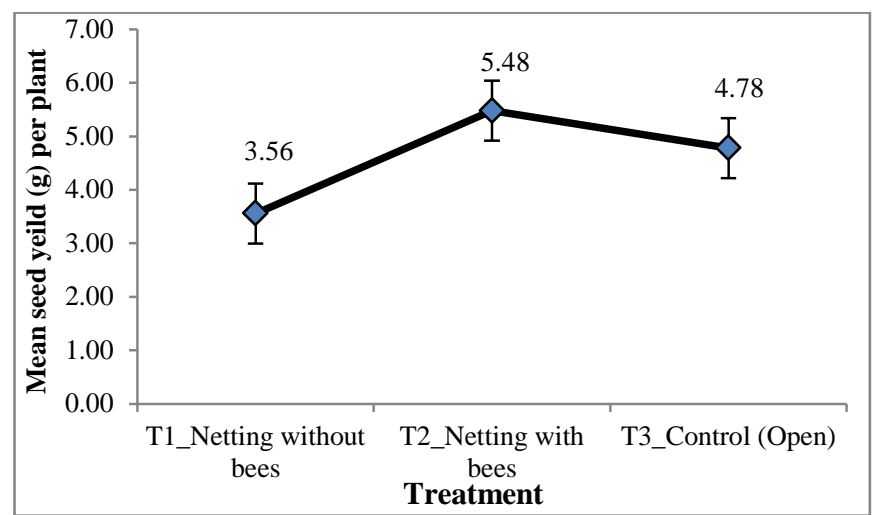

Fig. 6. Mean seed yield per plant in different treatments.

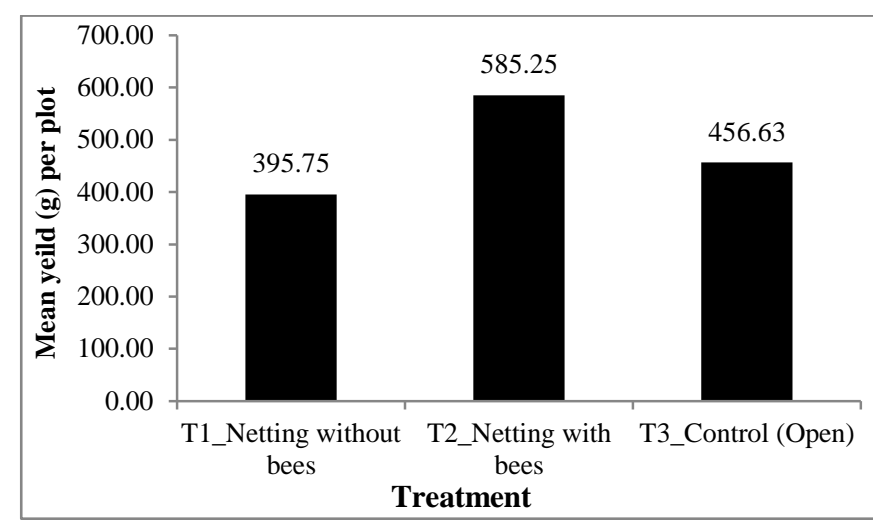

Fig. 7. Yield of mustard (g) per plot in different treatments.

The flowering of mustard period is generally from 50 to 55 days. Pollinator pressure causes well fertilization of flowers and therefore, in the netted condition with bees pod formation starts early in comparison to other two treatments. After fertilization, flowers petal sheds early; thus, the flowering period was less in the field with bee netted condition. Number of pod formation also increases with the condition of netted bees. On the other hand, pod length was higher compared to other treatments in open condition due to different pollinators' presence. Pod length is short in without bee condition of field due to lack of pollination and malformation of pod. Number of seeds was found higher in bee netted condition compared to other treatments due to well pollination, but the seed sizes are comparatively smaller hence resulted in the less weight of the 1000 number of mustard seeds. Though the seed size is small, but the total yield was the highest in the netted bee condition due to well pollination of mustard flower.

\section{REFERENCES}

Abrol, D. P. 1997. Bees and bee-keeping in India. 1st ed. Kalyani Publishers, Ludhiana, India. 45 pp.

Ameco. 2012. The possible role of honey bees in the spread of pollen from field trials. Plant Res. Inter. pp: 1-144.

BBS. 2017. Monthly Statistical Bulletin of the Bangladesh Bureau of Statistics (August). Administration and MIS Wing, Bangladesh Secretariat, Dhaka. 120 pp.

Devillers, J., M. H. Pham-Delegue, A. Decourtye, H. Budzinski, S. Cluzeau and G. Maurin. 2002. Structure-toxicity modeling of pesticides to honey bees. Environ. Res. 13: 641-648.

FAO. 1986. The tropical and Subtropical Agriculture. FAO Agriculture services bulletin 68, Food and agricultural Organization of the United Nations, Rome, Italy. 283 pp.

FAO. 2004. Production Year Book. Food and Agricultural Organization of the United Nations, Rome, Italy. 82: 190-193.

FAO. 2005. Protecting the pollinators. FAO spotlight. United Nations Food and Agriculture Organization. (http://www.fao.org/ag/magazine/0512sp1.htm) (Accessed 6 July 2015). 
Hardstone, M. C. and J. G. Scott. 2010. Is Apis mellifera more sensitive to insecticides than other insects? Pest Manag. Sci. 66(11): 1171-1180.

Krupke, C. H., G. J. Hunt, B. D. Eitzer, G. Andino and K. Given. 2012. Multiple routes of pesticide exposure for honey bees living near agricultural fields. PLoS One. 7(1): e29268.

Lawal, O. A. and A. D. Banjo. 2010. Appraising the beekeeping knowledge and perception of pest's problem in beekeeping business at different ecological zones in South-Western Nigeria. World J. Zool. 5: 137-142.

Lee, K. V., N. Steinhauer, K. Rennich, M. E. Wilson, D. R. Tarpy, D. M. Caron, and D. vanEngelsdorp. 2015. A national survey of managed honey bee 2013-2014 annual Colony losses in the USA. Apidologie. 46: 292-305.

Mohapatra, L. N., B. K. Sontakke and N. Rana singh. 2010. Enhancement of crop production through bee pollination. Orissa review. pp: 44-47.

Morse, R. A. and N. W. Calderone. 2000. The value of honeybees as pollinators of U.S. crops. J. Bee Culture. 3: 128.

Singh, R., B. K. Chaudhary, Bhowmick and R. P. Singh. 2005. Honeybee flora of Bihar, Uttar Pradesh and Madhy Pradesh. International Beekeeping Congress. 53 pp.

Stefanidou, M., S. Athanaselis and A. Koutselinis. 2003. The toxicology of honey bee poisoning. Vet. Hum. Toxicol. 45(5): 261-265.

Williams, I. H. 1994. The dependence of crop production within the European Union on pollination by honey bees. Agril Zool. Rev. 6: 229-257. 